\title{
Readiness for Organizational Change as a Mediator of Distributed Leadership Relationships and the Implementation of Professional Learning Community
}

\author{
Zalina Binti Zakaria*, Siti Noor Binti Ismail ${ }^{* *}$ \\ * School of Education and Modern Languages, Universiti Utara Malaysia \\ DOI: 10.29322/IJSRP.11.05.2021.p11353 \\ http://dx.doi.org/10.29322/IJSRP.11.05.2021.p11353
}

\begin{abstract}
This study aimed to identify the level of principals' distributed leadership practices, organizational readiness to change and PLC implementation. Other than that, this study as well aimed examine the influence of organizational to change as a mediating variable on the principal's distributed leadership with PLC implementation in school. A cross-sectional survey was used to collect data involving Kelantan, Malaysia secondary school teachers. A total of 371 teachers from the total population of 10866 were selected based on the graded sampling method. The instrument Distributed Leadership Readiness Scale (Gordon, 2005) was used to measure principals 'leadership practices, Professional Learning Communities-Revised (Oliver \& Hipp, 2010) to measure PLC implementation and Organizational Readiness to Change (Shea, 2014) was used to measure school change readiness. The data were analyzed using SPSS version 25.0 (Statistical Package for Social Sciences for Windows Version 25.0). The findings of the study indicate that there is a significant positive relationship between the influence of distributive leadership and organizational change readiness. Distributive leadership and organizational change readiness are predictor factors to PLC implementation. The vision, mission and goal setting dimension is the highest predictor dimension followed by leadership practices and leadership partnership while school culture is the lowest predictor. The dimensions of effectiveness to change and commitment to change in organizational change readiness indicate high predictors to the level of PLC implementation.
\end{abstract}

Index Terms- Distributed Leadership, Professional Learning Community, Readiness to Change, Organizational Change

\section{INTRODUCTION}

$\mathrm{T}$ he Ministry of Education Malaysia has launched the Malaysia Education Development Plan 2013-2025 (PPPM 2013-2025) in 2013. PPPM 2013-2025 is a long-term plan that contains eleven (11) shifts that outline the vision of Malaysian education including empowering school leadership and improving the quality of teachers to meet the aspirations of students. Education transformation needs to be implemented on strategic and operational aspects in line with the development of the rapidly developing education system (Malaysia Education Blueprint, 2013). Among the essence contained in the objective of empowering educational leadership is to boost distributive leadership and enhance the development of teacher professionalism in order to strengthen school management towards systematic organizational management (Ahmad Marzukil Mohamad, 2013; Bush, Abdul Hamid, Ng, \& Kaparou, 2018; Jones, Adams, Hwee Joo, Muniandy, Perera, \& Harris, 2015) with the integration of shared values towards producing skilled students (Rosnarizah Abdul Halim, \& Hussein Ahmad, 2015) as well as being able to compete on the global stage (Mahmood \& Othman, 2020). This coincides with the aspirations contained in education reform that is, all students should be given the opportunity to follow the learning and explore every field of knowledge to improve their expertise and skills and be able to compete in the global arena (Malaysia Education Blueprint, 2013). Therefore, the Malaysia Education Development Plan 2013-2025 emphasizes two main factors in determining the outcomes and potential of students, namely, the quality of school leadership and the quality of teaching. To achieve the desired objectives, the distributive leadership role of principals geared towards collaborative work, shared vision and mission, cultivating collaboration and consensus work will lead to not only teaching and learning approaches in the classroom but will impact organizational change (Khalifa, Gooden, \& Davis, 2016; Trilaksono, Purusottama, Misbach \& Prasetya, 2019; Siti Nafsiah Ismail, Zuraidah Abdullah, \& Abdul Jalil Othman, 2020). In other words, the transformation in the national education system needs to be implemented holistically which includes strengthening leadership and human capital competencies, change of mindset and way of acting, strengthening of values and integrity, paradigm shift, frame of mind and wise mobilization of resources. 
Strong leadership in administrative management, resource management and curriculum development is a key factor that will determine school excellence. Principal leadership will have an impact on the readiness of teachers to implement changes in all aspects including work culture as well as practices in the teaching and learning process (Ahumada, Maureira, \& Castro, 2019; Hamzah, \& Jamil, 2019). Readiness to implement change among school people can be implemented when the need and importance to implement change is clarified and appreciated by all school people. In other words, the willingness and commitment given by the school people will improve the performance of the organization.

\section{Statement of the Problem}

Typically, school success is linked to principal leadership while school excellence is always associated with the value of agreement, cooperation and commitment given by the entire school community (Sun \& Xia, 2018). Research shown principals who practice distributive leadership will have a positive impact on the learning process of students and can increase the motivation and support of school people in the perspective of providing an effective learning environment (Kallio \& Halverson, 2020). Excellence school leadership will support the formation of a positive school environment, culture and climate for student learning learning. Therefore, the readiness to change an organization or a school as a whole related to aspects of leadership, responsibility and functionality based on the assigned task descriptions chooses to significantly improve students learning. To realize student learning holistically, PLC is one of the best teacher professional development platforms that can be implemented in schools (Othman, Jamian, Sabil, Said, \& Omar, 2020).

PLC has been outlined in the Continuing Professional Development Program (Ministry of Education Malaysia, 2014) and enshrined in the Malaysian Education Development Plan (PPPM, 2013-2025). But to what extent can this implementation be done? Do all parties involved really understand their functions and responsibilities? Have school administrators as key leaders stimulated teachers 'motivation as motivating agents to act effectively? OECD report (2016) also revealed the finding that about one in three school principals do not foster a spirit of cooperation among teachers in schools. As such, the OECD has submitted policy proposals that include action plans to strengthen school leadership. Three of the six parts of this proposal plan are leadership and learning approaches involving PLC namely, (1) school leadership and professional learning community, (2) school leadership and positive learning climate development, and (3) school leadership and learning climate development and professional learning communities in secondary and primary schools (OECD, 2016).

\section{Purpose of the Study}

The main purpose of this study is to identify, explore and analyze responses to the influence and impact of distributive leadership in increasing the level of organizational change readiness and the level of PLC implementation while exploring the generating factors to effective PLC implementation in schools.

1. To identify the level of distributive leadership, the level of organizational change readiness and the level of PLC implementation in ordinary day secondary schools in Kelantan

2. To identify the role of organizational change readiness as a mediator for the relationship between distributive leadership and PLCs

\section{Research Questions}

The following research questions guided the study;

1. What is the level of distributive leadership, the level of organizational change readiness and the level of PLC implementation in Kelantan day secondary schools?

2. Does organizational change readiness serve as a mediator for the relationship between distributive leadership and PLCs?

\section{Hypothesis}

The relationship of distributive leadership and organizational change readiness with PLC implementation. The following hypotheses are formed and expressed in the form of null hypotheses.

H01 There is no significant relationship between distributive leadership and organizational change readiness

H02 There is no significant relationship between distributive leadership and PLC implementation

H03 There is no significant relationship between organizational change readiness and PLC implementation

H04 Readiness to change non -mediator organizations on the relationship between distributive leadership and PLC implementation

\section{METHODS}

\section{Study Methods, Population, Sampling and Data Analysis Methods}

This research paper is in the form of a quantitative study with cross -sectional survey method. A staged sampling method was also chosen with the main step being the division of the population into four zonal clusters. The selection of the quantitative method was chosen based on the objectives and questions of the study to obtain generalized findings to the study population. Research Methodology (2017) states that this scientific method is more purposeful, detailed, robust, more convincing and can be generalized. The population 
included all Residential Secondary School teachers in the state of Kelantan, Malaysia $(n=10866)$ and the number of samples taken was a total of 371 people as suggested by Krejcie and Morgan (1970). The method of managing the questionnaire is self-administered allowing the questionnaire to be managed well and retrieve the form more quickly. In addition, any doubts by the respondent during the answering process can be explained directly. Study data were analyzed using SPSS Version 25.

\section{Questionnaire}

The research instruments were compiled based on suitability and ability to assess the variables involved accurately based on a seven point Liket Scale. The instruments used in this study are divided into four parts; Part A, Part B, Part C and Part D . Part A contains the demographics of the respondents, Part B is the distributive leadership questionnaire, adapted from the Distributed Leadership Readiness Scale (Gordon, 2005), (40 items). While Part C is an Organizational Change Readiness, adapted from the Organizational Readiness for Implementing Change by Shea et al. , (2014), (12 items). Part D is a questionnaire adapted from Oliver and Hipp's (2010) Professional Learning Communities- Revised (PLC-R), (25 items). Based on the range of reliability indices, the questionnaire used for this study has a good and appropriate reliability value where all Cronbach Alpha values for each dimension are above 0.80 . This means that the questionnaire has good internal consistency for each item tested (Quansah, 2017).

The data collected were analyzed using mean and standard deviation to answer the research questions and determine the homogenity or otherwise of the respondents views.

Tabble 1:

Interpretation of Mean Skor

\begin{tabular}{lc}
\hline \multicolumn{1}{c}{ Tahap } & Skor Min \\
\hline Very Low & $1.00-1.84$ \\
Low & $1.85-2.70$ \\
Medium Low & $2.71-3.56$ \\
Medium & $3.57-4.42$ \\
Medium High & $4.43-5.28$ \\
High & $5.29-6.14$ \\
Very High & $6.15-7.00$ \\
\hline
\end{tabular}

( Alotaibi et al., 2017)

\section{RESULT}

Resultof the study were presented in the table below.

Research Question 1: What is the level of distributive leadership, the level of organizational change readiness and the level of PLC implementation in Kelantan day secondary schools?

Table 2:

Mean Score of Distributed Leadership and Dimensions

\begin{tabular}{llll}
\hline Variables and Dimensions & Mean & SD & Remark \\
\hline Distributed Leadership & 5.43 & .66 & $\mathrm{H}$ \\
School Culture & 5.53 & .71 & $\mathrm{H}$ \\
Sharing Responsibility & 5.44 & .73 & $\mathrm{H}$ \\
Vision, Mision \& School Objective & 5.35 & .72 & $\mathrm{H}$ \\
Leadership Practices & 5.33 & .75 & $\mathrm{H}$ \\
\hline
\end{tabular}

Descriptive analysis showed that the level of distributive leadership was high $(\mathrm{M}=5.43, \mathrm{SD}=.66)$. This result is obtained since all dimensions in the distributive leadership construct are also in a high range, namely $(\mathrm{M}=5.33 ; \mathrm{SD}=.75)$ to $(\mathrm{M}=5.53 ; \mathrm{SD}=.71)$.

Table 3:

Mean Score of Organizational Readiness to Change and Dimensions

\begin{tabular}{lccc}
\hline Variables and Dimensions & Mean & SD & Remark \\
\hline Organizational Readiness to Change & 5.30 & .58 & $\mathrm{H}$ \\
Commitment to Change & 5.41 & .86 & $\mathrm{H}$ \\
Efficacy to Change & 5.24 & .81 & $\mathrm{MH}$ \\
\hline
\end{tabular}

Descriptive analysis showed that the level of organizational change readiness was high $(\mathrm{M}=5.30, \mathrm{SP}=.58)$. This result is obtained given that all the dimensions in the organizational change readiness construct are also in the high and medium high.

Table 4:

Mean Score of PLC Implementation and Dimensions

\begin{tabular}{cccc}
\hline Variables and Dimensions & Mean & SD & Remark \\
\hline PLC implementation & 5.47 & .73 & H \\
Collective Learning Application & 5.64 & .79 & H
\end{tabular}

This publication is licensed under Creative Commons Attribution CC BY. 
Supportive Condition(Relationship)

Sharing Values and Vision

Supportive Condition (Structure)

Partnership and Leadership Support

Sharing Best Practices

$\begin{array}{lll}5.50 & .78 & \mathrm{H} \\ 5.46 & .85 & \mathrm{H} \\ 5.45 & .83 & \mathrm{H} \\ 5.38 & .92 & \mathrm{H} \\ 5.37 & .83 & \mathrm{H}\end{array}$

The results of the descriptive analysis show the mean score for the level of PLC implementation and the mean score for each dimension in PLC implementation.

Research Question 2: Does organizational change readiness serve as a mediator for the relationship between distributive leadership and PLCs?

Baron and Kenny (1986) who stated that mediators were tested using three regression models namely:-

i. The first model is regression to predict dependent variables (PLC implementation) from independent variables (distributive leadership).

ii. The second model is regression to predict the mediator variable (organizational change readiness) from the independent variable (distributive leadership).

iii. The third model is regression to predict the dependent variable (PLC implementation) from the independent variable (distributive leadership) and the mediator variable (organizational change readiness).

Table 5:

Multiple Regression Analysis of The Influence of Distributive Leadership on PLC Implementation and Organizational Change Readiness

\begin{tabular}{lccc}
\hline Variable & \multicolumn{2}{c}{ PLC Implementation } & $\begin{array}{c}\text { Organizational } \\
\text { Readiness to Change }\end{array}$ \\
\hline $\begin{array}{l}\text { Distributed Leadership } \\
\text { Organizational Readiness }\end{array}$ & to & $0.33^{* *}$ & $0.43^{* *}$ \\
Change & & $0.44^{* *}$ & \\
\hline$R^{2}$ & & & 0.19 \\
$R^{2}$ adjusted & 0.11 & 0.19 & 0.18 \\
$F$ & 0.11 & 69.44 & 68.55 \\
\hline
\end{tabular}

Significant at 0.05

The findings of the study indicate that distributive leadership accounts for 11 percent of the variance change in PLC implementation and 19 percent of the variance change in organizational readiness to change. Meanwhile, organizational readiness to change contributed 19 percent of the variance change in PLC implementation. This means that distributive leadership has a small impact $(\mathrm{R} 2=0.11)$ on PLC implementation and a moderate impact $(\mathrm{R} 2=0.19)$ on organizational readiness to change. organizational readiness to change had a moderate effect $(\mathrm{R} 2=0.19)$ on PLC implementation. In addition, the findings also show that distributive leadership has a moderate and significant influence on the implementation of PLC $(\beta=0.33, p=0.00)$ and also on organizational readiness to change $(\beta=0.43$, $p$ $=0.00)$ at the level of $\mathrm{p}<0.05$. Similarly, the readiness of organizational change had a moderate and significant influence on the implementation of $\operatorname{PLC}(\beta=0.44, \mathrm{p}=0.00)$ at the level of $\mathrm{p}<0.05$.

To answer the hypothesis involving Pearson correlation analysis, the strength of the relationship was measured based on the value of the coefficient $r$.

Table 6:

Value and Coefficient $\mathbf{r}$ Correlation Interpretation

\begin{tabular}{cc}
\hline Value of Coefficient $r$ & Correlation interpretation \\
\hline 0.00 & nonexist \\
$0.10-0.39$ & Weak \\
$0.40-0.69$ & Moderate \\
$0.70-0.99$ & High \\
1.00 & perfect \\
\hline
\end{tabular}

(Dancey \& Reidy, 2017)

Hypothesis 1: There is no significant relationship between distributive leadership and organizational change readiness

Table 7:

Pearson Correlation Analysis for Distributed Leadership and Organizational Readiness to Change Relationship

\begin{tabular}{lcccc}
\multicolumn{1}{c}{ Variable } & Mean & SD & 1 & 2 \\
\hline 1. Distributel Leadership & 5.43 & .66 & 1.00 & $.75^{* *}$ \\
2. Organizatonal Readiness to Change & 5.30 & .58 & 1.00 \\
\hline
\end{tabular}

This publication is licensed under Creative Commons Attribution CC BY. 
$* * \mathrm{p}<.01(2$-tail)

The value of Pearson coefficient shows a very strong positive relationship and this value is significant ( $p<.01)$. This $r$ value explains the indicator of the existence of a significant and high positive relationship (Dancey \& Reidy, 2017) between distributive leadership with organizational readiness to change, $\mathrm{r}=.75, \mathrm{n}=371, \mathrm{p}<.01$, hence the value of the coefficient of determination, $\mathrm{r} 2=.56$, means that $56 \%$ of the level of organizational change readiness is contributed by distributive leadership variables.

Hypothesis 2: There is no significant relationship between distributive leadership and PLC implementation

Table 8:

Pearson Correlation Analysis for Ditributed Leadership and PLC Implementation Relationship

\begin{tabular}{lcccc}
\hline \multicolumn{1}{c}{ Variable } & Mean & SD & 1 & 2 \\
\hline 1. Distributed Leadership & 5.43 & .66 & 1.00 & $.80^{* *}$ \\
2. PLC Implementation & 5.47 & .73 & 1.00 & \\
\hline
\end{tabular}

** p<.01 (2-tail

The value of Pearson coefficient shows a very strong positive relationship and this value is significant ( $p<.01)$. This $r$ value explains the indicator of the existence of a significant and high positive relationship (Dancey \& Reidy, 2017) between distributive leadership with PLC implementation, $\mathrm{r}=.80, \mathrm{n}=371, \mathrm{p}<.01$, hence the value of the coefficient of determination, $\mathrm{r} 2=.64$, meaning $64 \%$ of the PLC implementation level is contributed by distributive leadership variables.

Hypothesis 3: There is no significant relationship between organizational change readiness and PLC implementation

Table 9:

Pearson Correlation Analysis for Organizational Readiness to Change and PLC Implementation Relationship

\begin{tabular}{lcccc}
\hline \multicolumn{1}{c}{ Variable } & Mean & SD & 1 & 2 \\
\hline 1. Organizational Readiness to Change & 5.30 & .58 & 1.00 & $.74^{* *}$ \\
2. PLC implementation & 5.47 & .73 & 1.00 \\
\hline
\end{tabular}

$* * \mathrm{p}<.01$ (2-tail)

The value of the correlation coefficient in indicates a strong positive relationship and this value is significant ( $p<.01$ ). This $r$ value explains the indicator of the existence of a significant and high positive relationship (Dancey \& Reidy, 2017) between organizational change readiness with PLC implementation, $\mathrm{r}=.74, \mathrm{n}=371, \mathrm{p}<.01$, hence the value of coefficient of determination, $\mathrm{r} 2=.55$, meaning $55 \%$ of the PLC implementation level is contributed by the organizational change readiness variable.

Hypothesis 4: Organizations Readiness to Change is non-mediator on the relationship between distributive leadership and PLC implementation

Table 10:

Results of Multiple Regression Test Readiness of Organizational Change as a Mediator in Interpersonal Relationships Distributive Leadership With PLC Implementation

\begin{tabular}{|c|c|c|c|}
\hline \multirow[t]{2}{*}{ Variabel } & \multicolumn{3}{|c|}{ Dependent Variable } \\
\hline & PLC Implementation & $\begin{array}{l}\text { PLC Implementation } \\
\text { (without mediator) }\end{array}$ & $\begin{array}{l}\text { PLC Implementation } \\
\text { (with mediator) }\end{array}$ \\
\hline $\begin{array}{l}\text { Independent Variable } \\
\text { Distributed Leadership } \\
\text { Mediator Variable }\end{array}$ & & $0.33 * *$ & $0.17 * *$ \\
\hline Organizational Readiness to Change & $0.44^{* *}$ & & $0.36 * *$ \\
\hline$R^{2}$ & 0.19 & 0.11 & 0.21 \\
\hline$R^{2}$ adjusted & 0.19 & 0.11 & 0.21 \\
\hline$F$ & 69.44 & 36.20 & 40.31 \\
\hline
\end{tabular}

Significant at 0.05

Analysis showed that the independent variable (distributive leadership) had a significant influence on the dependent variable (PLC implementation) without the presence of the mediator variable (organizational change readiness) $(\beta=0.33, \mathrm{p}<0.05)$ and also significant with the mediator variable (organizational change readiness) $)(\beta=0.17, \mathrm{p}<0.05)$ as well as the beta value of the coefficient $(\beta)$ decreased. Thus, organizational change readiness acts as a partial mediator in the relationship between distributive leadership and PLC 
implementation. Thus, in conclusion, the organizational readiness to change is a mediator to distributive leadership and the implementation of PLC in Kelantan Secondary Residential School.

\section{DISCUSSIONS AND FINDINGS}

Descriptive analysis showed that the level of distributive leadership was high $(\mathrm{M}=5.43$, SD $=.66)$. This result is obtained since all dimensions in the distributive leadership construct are also in a high range, namely $(\mathrm{M}=5.33 ; \mathrm{SD}=.75)$ to $(\mathrm{M}=5.53 ; \mathrm{SD}=.71)$. The findings of this study are in line with the findings of the study Thien, Adams, Koh, (2021), as well as Estrada (2017) who stated that distributive leadership can foster a positive work culture and increase teacher commitment to the organization. These findings are also in line with a study conducted by Syahrul Azizi and Abdullah, (2020), who stated that distributive leadership is a framework thinking that encourages more individuals to engage in leadership formally or informally.

Descriptive analysis showed that the level of organizational readiness to change was high $(\mathrm{M}=5.30, \mathrm{SD}=.58)$. This result is obtained since all dimensions in the construct of organizational change readiness are also in the high and medium high range, namely the dimension of commitment to change that has a high mean value $(\mathrm{M}=5.41, \mathrm{SD}=.86)$ and the dimension of effectiveness to change that is at moderately high level $(\mathrm{M}=5.24, \mathrm{SD}=.81)$. The findings also show that there is a high commitment among teachers to implement change $(M=5.30, S D=.58)$. Teachers' willingness to change and implement change is a network of cooperation that exists in schools. Without the willingness of teachers to implement change, it will not affect the progress of the school. This finding is in line with a study conducted by Wang, Olivier, \& Chen (2020) who stated that the success of an organization to implement change not only lies in the commitment of its citizens but, the extent to which members of the organization understand the need for change, which is a determining factor. to the success of an organization.

Linear regression analysis for distributive leadership variables against PLC implementation showed that R2 $=.64$, which explains the value of variance for PLC implementation associated with distributive leadership predictor variable was $64 \%$, with value $\beta=.80$. The importance of the organizational change readiness variable as a mediator of the relationship between distributive leadership and PLC implementation in residential secondary schools has been demonstrated in this study. These results indicate that both dimensions of organizational change readiness, namely commitment to change and effectiveness of change can significantly and positively explain the relationship that exists between distributive leadership and PLC implementation.

\section{CONCLUSION}

The findings of the study indicate that distributive leadership factors and readiness to implement change in school people influence the effective implementation of PLC. The support of principals and school administrators will increase the cooperation, commitment and sense of responsibility of teachers towards student achievement. Therefore, PLC needs to be strengthened in its implementation and used as a platform for teachers to increase their level of professional development. As a conclusion of this study, the researcher has built a new model that involves all the variables involved which highlights the important dimensions of distributive leadership and organizational change readiness that contribute to effective implementation of PLC and subsequently realize school organizational excellence in particular and educational excellence in general.

\section{RECOMMENDATIONS}

Based on the findings of the study, the following recommendations are made,

1. PLC is an important field of knowledge and the level of practice in schools is still not well established. Based on the study, teachers still can not relate the role of school culture and the setting of the vision, mission, objectives and goals of the school can contribute to learning and student achievement. Therefore, it is hoped that this study can provide guidance to principals and teachers to implement PLC in schools.

2. The level of PLC implementation needs to be improved and intensified to produce quality teachers that are synonymous with current educational developments. Teachers have been exposed to KBAT, iThink, google classroom and various online access applications to empower the level of teacher professionalism development. Therefore, schools can use the PLC platform as a mechanism to make this learning a success.

3. Through this study it has also been found that there are two main dimensions of distributive leadership that contribute to the effective implementation of PLC in schools, namely, the sharing of personal practices and also the sharing of leadership. Meanwhile, the other two dimensions, namely school culture and setting the vision, mission and objectives of the school make a very small contribution. Therefore, the school needs to improve this dimension through the preparation of guidelines and provide more systematic documentation so that every member of the school community can benefit from the changes implemented. 


\section{REFERENCES}

[1] Ahmad MarzukiI Mohamad. (2013). Amalan kepimpinan Islam pengetua dan perkaitannya terhadap atribut komuniti pembelajaran profesional. Tesis Ijazah Doktor Falsafah.

[2] Ahumada, L., Maureira, O., \& Castro, S. (2019). Strengthening distributed leadership in schools through collaborative research. Profesorado. https://doi.org/10.30827/profesorado.v23i2.9252

[3] Baron, R. M., \& Kenny, D. A. (1986). Baron \& Kenny, 1986. Journal of Personality and Social Psychology.

[4] Bush, T., Abdul Hamid, S., Ng, A., \& Kaparou, M. (2018). School leadership theories and the Malaysia Education Blueprint. International Journal of Educational Management. https://doi.org/10.1108/ijem-06-2017-0158

[5] Dancey, C., \& Reidy, J. (2017). Correlational analysis: Pearson's r. In Statistics Without Maths for Psychology.

[6] Estrada, M. (2017). Organizational change in public schools: The use of small groups. Dissertation Abstracts International Section A: Humanities and Social Sciences.

[7] Hamzah, M. I. M., \& Jamil, M. F. (2019). The Relationship of Distributed Leadership and Professional Learning Community. Creative Education https://doi.org/10.4236/ce.2019.1012199

[8] Jones, M., Adams, D., Hwee Joo, M. T., Muniandy, V., Perera, C. J., \& Harris, A. (2015). Contemporary challenges and changes: principals' leadership practices in Malaysia. Asia Pacific Journal of Education. https://doi.org/10.1080/02188791.2015.1056591

[9] Kallio, J. M., \& Halverson, R. (2020). Distributed leadership for personalized learning. Journal of Research on Technology in Education https://doi.org/10.1080/15391523.2020.1734508

[10] Khalifa, M. A., Gooden, M. A., \& Davis, J. E. (2016). Culturally Responsive School Leadership: A Synthesis of the Literature. Review of Educational Research https://doi.org/10.3102/0034654316630383

[11] Krejcie, R. V, \& Morgan, D. W. (1970). Krejcie \& Morgan. Educational and Psychological Measurement.

[12] Mahmood, M. S., \& Othman, M. K. (2020). Learning style practices and critical thinking of students in Malaysia. Universal Journal of Educational Research. https://doi.org/10.13189/ujer.2020.080833

[13] Malaysia Education Blueprint, M. (2013). Malaysia Education Blueprint 2013 - 2025. Education. https://doi.org/10.1016/j.tate.2010.08.007

[14] OEDC. (2016). Innovating Education and Educating for Innovation: The Power of Digital Technologies and Skills. In Educational Research and Innovation.

[15] Quansah, F. (2017). The Use Of Cronbach Alpha Reliability Estimate In Research Among Students In Public Universities In Ghana. African Journal of Teacher Education. https://doi.org/10.21083/ajote.v6i1.3970

[16] Research Methodology. (2017). Cluster Sampling - Research Methodology. Research Methodology.

[17] Rosnarizah Abdul Halim, \& Hussein Ahmad. (2015). Kepemimpinan Distributif, Faktor Kontekstual dan Efikasi Kendiri Guru di Malaysia. Jurnal Kepimpinan Pendidikan.

[18] S. Syahrul Zarizi S. Abdullah. (2020). Pengaruh kepimpinan distributif terhadap komuniti pembelajaran profesional dalam kalangan pemimpin sekolah menengah di negeri Johor. Sains Humanika.

[19] Siti Nafsiah Ismail, Zuraidah Abdullah, \& Abdul Jalil Othman. (2020). Komuniti pembelajaran profesional guru bahasa melayu Malaysia. Jurnal Kepimpinan Pendidikan.

[20] Sun, A., \& Xia, J. (2018). Teacher-perceived distributed leadership, teacher self-efficacy and job satisfaction: A multilevel SEM approach using the 2013 TALIS data. International Journal of Educational Research. https://doi.org/10.1016/j.ijer.2018.09.006

[21] Thien, L. M., Adams, D., \& Koh, H. M. (2021). Nexus between distributed leadership, teacher academic optimism and teacher organisational commitment: a structural equation modelling analysis. International Journal of Educational Management. https://doi.org/10.1108/IJEM-05-2020-0278

[22] Trilaksono, T., Purusottama, A., Misbach, I. H., \& Prasetya, I. H. (2019). Leadership change design: A professional learning community (PLC) project in eastern Indonesia. International Journal of Evaluation and Research in Education. https://doi.org/10.11591/ijere.v8i1.15662

[23] Wang, T., Olivier, D. F., \& Chen, P. (2020). Creating individual and organizational readiness for change: conceptualization of system readiness for change in school education. International Journal of Leadership in Education. https://doi.org/10.1080/13603124.2020.1818131

\section{AUTHORS}

First Author - Zalina Binti Zakaria, Secondary School Principal, Cherang Ruku Secondary School, Kelantan, Malaysia, Post Graduates Student at Universiti Utara Malaysia, zalina.zz@gmail.com.

Second Author - Asso. Prof. Dr. Siti Noor Binti Ismail, School of Education and Modern Languages, College of Arts and Sciences,Universiti Utara Malaysia. 